"Factors determining the use of cloud computing in enterprise management in the EU (considering the type of economic activity)"

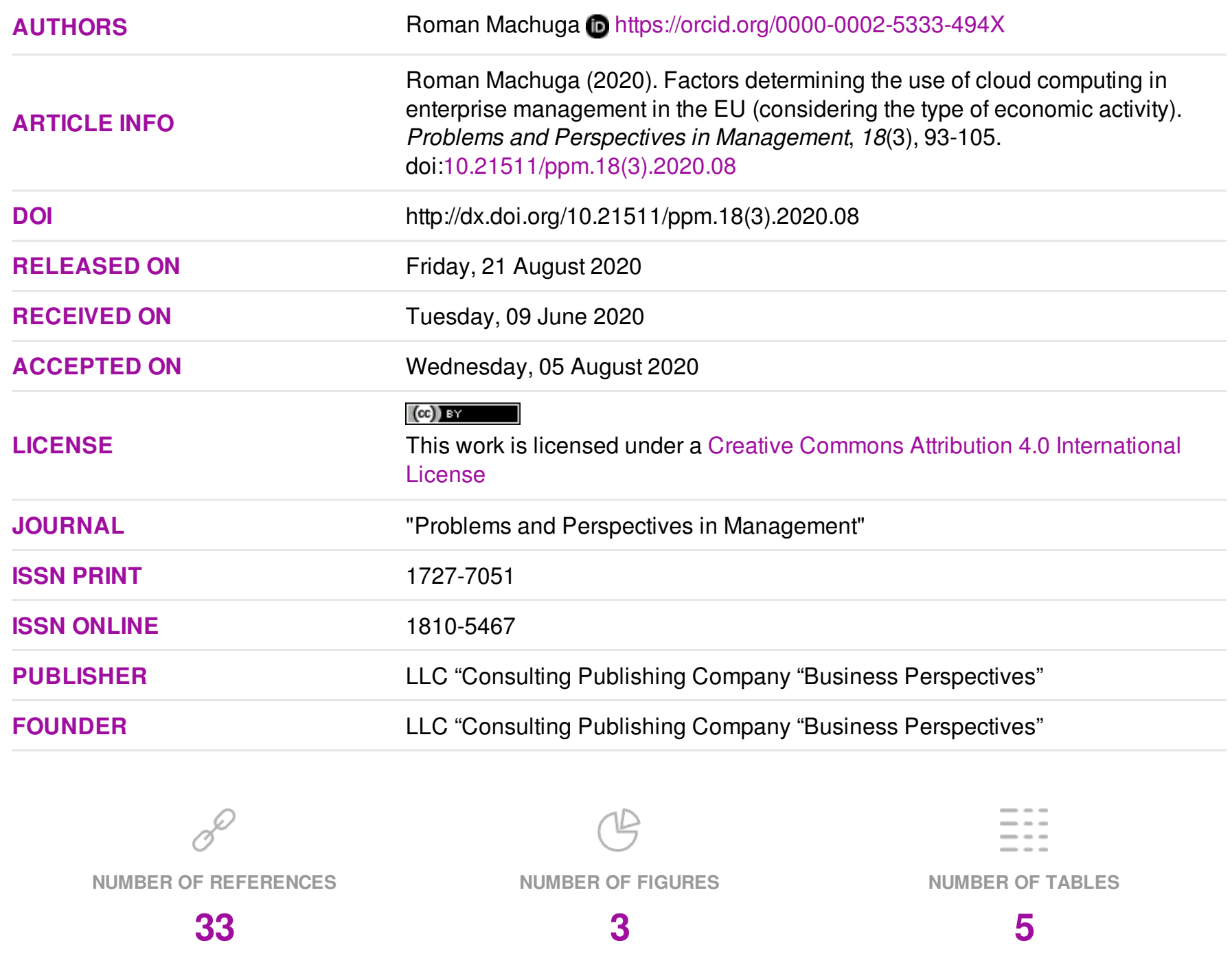

(C) The author(s) 2022. This publication is an open access article. 


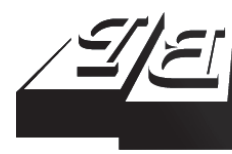

BUSINESS PERSPECTIVES

(O)

LLC "CPC "Business Perspectives"

Hryhorii Skovoroda lane, 10,

Sumy, 40022, Ukraine

www.businessperspectives.org
Received on: $9^{\text {th }}$ of June, 2020 Accepted on: $5^{\text {th }}$ of August, 2020 Published on: $21^{\text {st }}$ of August, 2020

(c) Roman Machuga, 2020
Roman Machuga, Master of Engineering, Ph.D., Assistant, Institute of Management and Quality, Faculty of Economics, University of Warmia and Mazury in Olsztyn, Olsztyn, Poland.
This is an Open Access article, distributed under the terms of the Creative Commons Attribution 4.0 International license, which permits unrestricted re-use, distribution, and reproduction in any medium, provided the original work is properly cited.

Conflict of interest statement: Author(s) reported no conflict of interest

\section{FACTORS DETERMINING THE USE OF CLOUD COMPUTING IN ENTERPRISE MANAGEMENT IN THE EU (CONSIDERING THE TYPE OF ECONOMIC ACTIVITY)}

\begin{abstract}
The use of cloud technology in business provides for many benefits. The use of cloud computing in business management varies greatly across the EU. The answer to the question of what factors influence the level of cloud computing usage in enterprises can be used to boost the utilization of cloud technologies and contribute to their popularization in Poland.

This study aims to identify the factors and assess their influence on the level of cloud computing use in enterprise management, considering business activity types.

The study is based on secondary data published periodically by the Eurostat. The study uses the r-Pearson correlation analysis. Statistical data for all EU countries for the period 2014-2018 was analyzed. Nine factors were selected for the correlation analysis. After verifying the research hypothesis, it was proven that there is a statistically significant relationship between the extent to which cloud computing is used in enterprises with different types of business activities and the selected factors. It was clearly shown that the percentage of the ICT sector in national GDP has no impact on the use of cloud technologies. Other research hypotheses were confirmed or partially confirmed.

A ranking of factors influencing the use of cloud technologies in enterprises, taking into account the type of business activity, was compiled. The obtained results will be useful to theoreticians and practitioners in developing a company's growth strategy and making decisions on modernizing the information structure or company virtualization.
\end{abstract}

\section{Keywords}

cloud computing, administration, business, European Union, Poland, sectors of the economy

JEL Classification L86, M11, M15

\section{INTRODUCTION}

Nowadays, information and communication technologies are the main instruments for information exchange and management. Information and production processes in a company are increasingly controlled using modern Internet solutions. The effectiveness of company management is often highly dependent on the use of modern ICT. Such technologies are used for searching, grouping and sharing information, for customer relationship management, direct control of production processes, or comprehensive management of company operations. Applications used for this purpose can be installed on computers both locally or on the internet. These applications can also be accessed directly from desktop computers or remotely from any mobile device. It should be stressed that nowadays, companies are increasingly trying to replace, where possible, an ordinary office with a home office, which requires organizing access to the company's IT resources. Various Internet technologies are used for this, and cloud computing is now very popular. 
The use of cloud computing allows companies to remotely access their e-mails, manage customer relationships and their databases, engage in Internet sales, organize a virtual office, and comprehensively manage the company through networked ERP (Enterprise Resource Planning) systems. Cloud technologies can also be used in various functional areas of an enterprise, i.e. in marketing and sales, in production and materials management, in accounting and finance, in human resources management.

Even though cloud computing offers many different benefits, their use in business varies greatly across the EU. For some countries, the difference is several-fold. This is confirmed by statistics from the Eurostat. Identification of factors affecting the level of cloud application use could facilitate the implementation of modern information solutions and increase the virtualization degree of enterprises in the EU countries, especially in Poland as a country with a low level of cloud computing use.

\section{LITERATURE REVIEW}

\subsection{Popularity and trends in cloud computing}

The concept of cloud computing "is very broad and ambiguous; in the broadest sense, it includes everything that is processed outside a local firewall" (Górecki, 2014). Today's literature on cloud computing includes various definitions of cloud computing, with the most commonly used being "a model that allows universal, convenient, on-demand network access to a common pool of configurable processing resources (e.g., networks, servers, storage resources, applications, and services) that can be quickly delivered and released with minimal management or action by the service provider" (Mell \& Grance, 2011). This definition is the most useful as it provides the most adequate summary description of the possibilities offered by these technologies These authors also distinguish three models of clouds: SaaS (Software as a Service), PaaS (Platform as a Service) and IaaS (Infrastructure as a Service). These cloud computing models vary in popularity across enterprises.

The first materials and publications on the use of cloud computing appeared in 2003-2007, for example: "Cloud computing: a method to realize conceptual computing" (Guoding \& Hong, 2003) or "Google and I.B.M. Join in 'Cloud Computing' Research" (Lohr, 2007). On the other hand, basic definitions concerning cloud computing were developed and published only in 2011. Cloud computing has been attracting attention since 2007, as confirmed by the Google trend (Google Trends, 2020a) for the search term "cloud computing" (geographical coverage - worldwide, time range - January 1, 2006 - May 21, 2020). It should be noted that the search phrase gained maximum popularity in 2010-2011. Moreover, this trend demonstrates the popularity of three main cloud computing models, namely SaaS, PaaS, and IaaS. It should be also noted that in the period under consideration, the popularity of the "SaaS" queries remains almost unchanged. The "PaaS" query has become equally popular in recent years. For example, in 2018, the number of queries for "SaaS" and "PaaS" was 2.8-2.9 times higher than for "cloud computing". Another Google trend (Google Trends, 2020b) is indicative of similar visualizations limited to individual countries as it exhibits a decrease in interest in the "cloud computing" query in 2011-2019, while the "SaaS" query is still gaining popularity.

While the first publications on cloud computing appeared in 2003-2007, the basic terminology was not developed until 2011, and the collection of statistical data on the levels of cloud computing use in enterprises (for example, in EU countries) did not start until 2014 (Eurostat, 2019a). It follows that, for the time being, analyzing the dynamics of cloud computing use in enterprises is only possible on the basis of data for 2014-2018. The statistics are gathered based on point B.2 of Annex 1 of Commission Regulation (EU) No, 2017/1515 of August 31, 2017 for enterprises "[...] with 10 or more employees. Enterprises with less than $10 \mathrm{em}$ ployees may be included in the survey on a voluntary basis" (EU Commission, 2017). This explains why Eurostat's statistical tables do not provide data on cloud usage in micro-enterprises. Therefore, the lack of such data prevents the analysis of cloud usage levels. Micro-enterprises have a great share in the business in general. For example, in Poland 
in April 2020, the structure of enterprises by size was as follows: micro (0-9) - 96.30\%; small (1049) - 2.99\%; medium (50-249) - 0.61\%; and large $(\geq 250)-0.09 \%{ }^{1}$. Therefore, the lack of such data makes it impossible to reflect the current level of interest and use of cloud technologies in micro-enterprises.

\subsection{The current state of cloud computing use in business in Poland and the EU countries}

One of the indicators used for several years to assess the development of the digital economy in the EU is the DESI index. This index from 2018 shows that Denmark, Sweden and Finland are the countries with the highest level of digital economy development, while the least developed countries are Bulgaria, Greece and Romania. In this classification, Poland ranked 24th out of 28 (European Commission, ${ }^{2018} \mathrm{a}$ ). The DESI index includes various indicators. Internet usage is one of them. Among others, it is influenced by the level of cloud computing use by enterprises (European Commission, ${ }^{2018}$ b, p. 2.
Regardless of the rapid development of information and communication technologies and their widespread use in everyday life, the use of cloud computing in practice varies considerably across the European Union (Machuga, 2017). Figure 1 shows the ranking of EU member states according to the levels of cloud computing use in enterprises.

Finland is the EU country with the highest level of cloud computing use in both 2018 and previous years (2014-2017). Poland ranks close to the end. However, it is worth stressing that in 2014-2018 positive dynamics is noticeable in Poland. The use of cloud computing services in enterprises increases annually by $1 \%$ (in 2017 by $2 \%$ ). The dynamics are positive, but still low compared to the EU average and the dynamics of Finland. Figure 2 shows a comparison of the number of enterprises (percentage value) that bought cloud services in Poland, the EU, and Finland in 2014-2018.

According to statistical data, the level of cloud computing use depends on the type of business. Groups of business types are shown in Table 1.

Source: Developed by the author based on Eurostat (2019a).

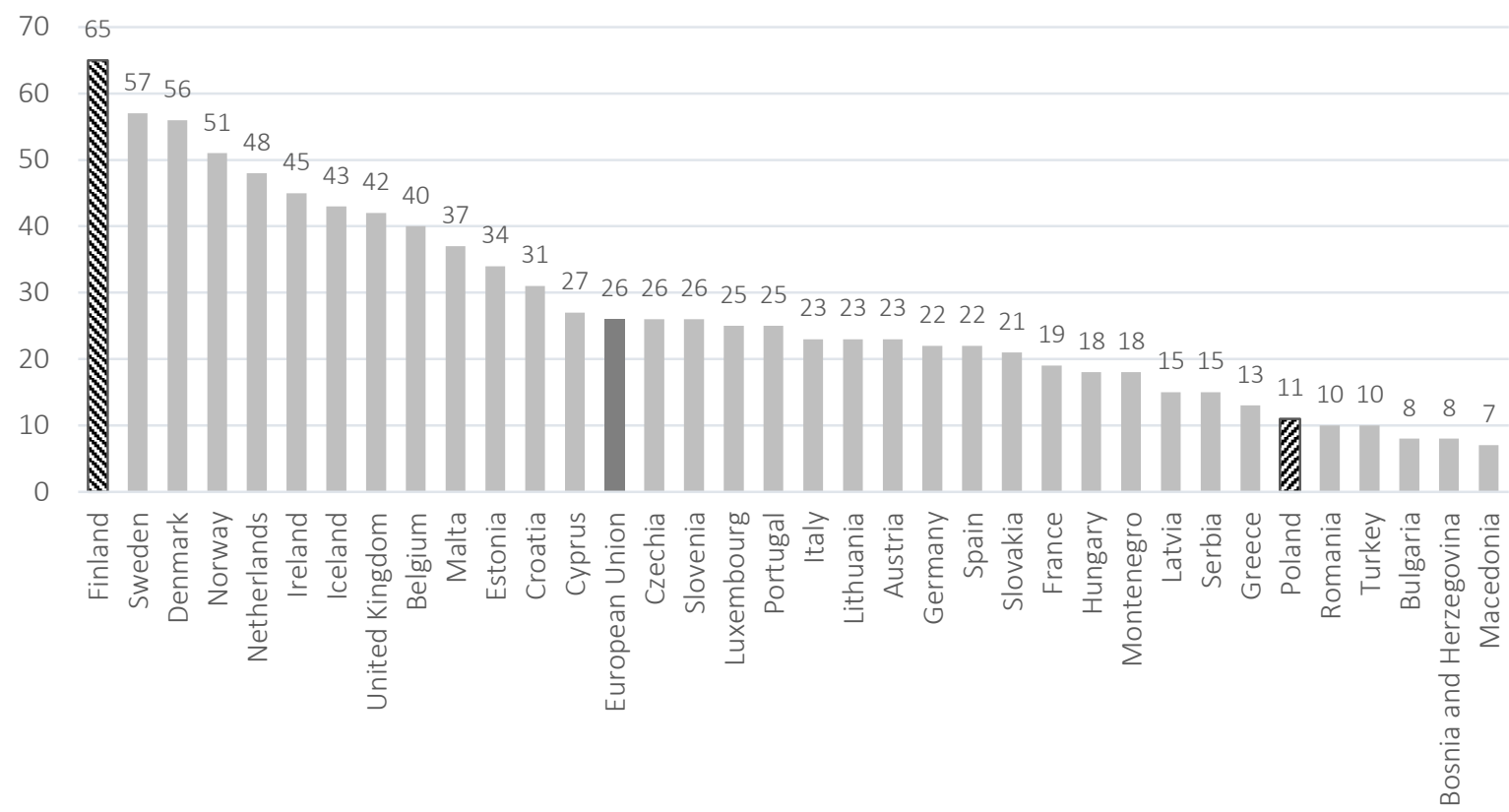

Figure 1. Percentage of companies in EU countries that bought cloud computing services in 2018

1 Own data analysis based on Statistics Poland, Monthly information on business entities in the REGON register April 2020, https://stat. gov.pl/obszary-tematyczne/podmioty-gospodarcze-wyniki-finansowe/zmiany-strukturalne-grup-podmiotow/miesieczna-informacja-opodmiotach-gospodarki-narodowej-w-rejestrze-regon-kwiecien-2020,4,34.html. 


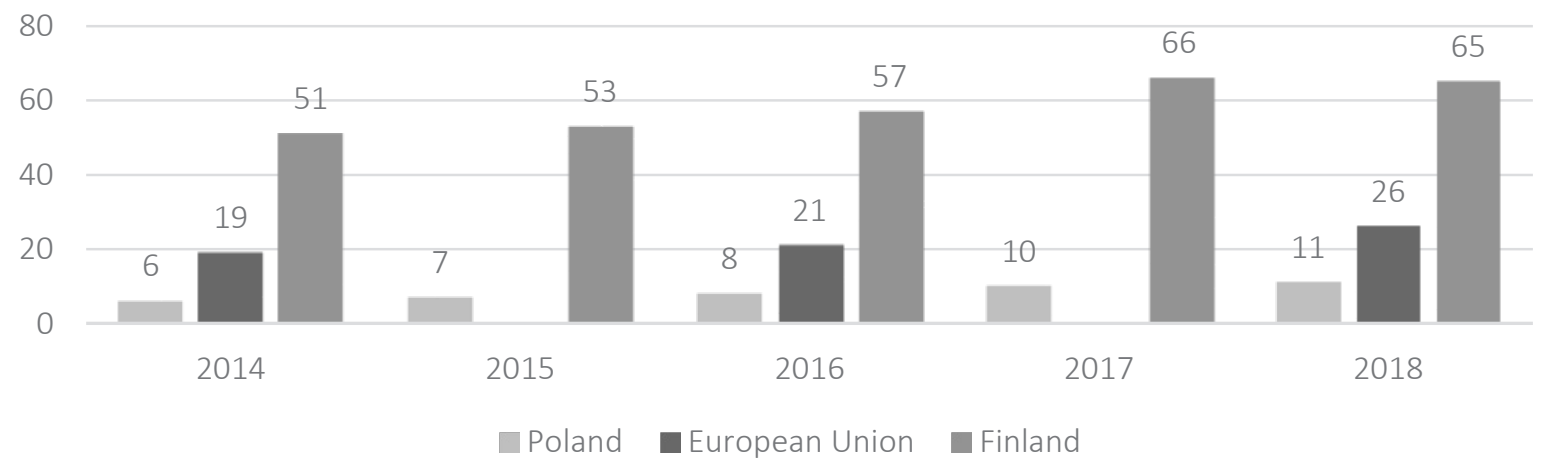

Figure 2. Percentage of enterprises that bought cloud computing services

Figure 3 shows the dependence between the percentage of enterprises using cloud computing and the type of business activity. The presented percentages of Polish enterprises using cloud computing reach their maximum for companies in categories
"7. Information and communication" (44\%), "11. ICT sector" (41\%), and "9. Professional, scientific and technical activities" (22\%). Minimum values were observed for "3. Construction" (6\%), "5. Transportation and storage" (9\%), and "1. Manufacturing" and

Table 1. Types of business ${ }^{2}$

Source: Developed by the author based on EU Commission (2017, pp. 11-12) and Eurostat (2019a).

\begin{tabular}{|c|c|c|}
\hline No. & Name & Sections and divisions ${ }^{3}$ \\
\hline 1 & Manufacturing & C10-33 \\
\hline 2 & Electricity, gas, steam, air conditioning, and water supply & D35-E39 \\
\hline 3 & Construction & F41-43 \\
\hline 4 & Wholesale and retail trade; repair of motor vehicles and motorcycles & G45-47 \\
\hline 5 & Transportation and storage & H49-53 \\
\hline 6 & Accommodation & 155 \\
\hline 7 & Information and communication & $J 58-63$ \\
\hline 8 & Real estate activities & L68 \\
\hline 9 & Professional, scientific and technical activities & M69-74 \\
\hline 10 & Administrative and support service activities & N77-82 \\
\hline 11 & ICT sector & ICT_T \\
\hline
\end{tabular}

Source: Developed by the author based on (Eurostat, 2019a).

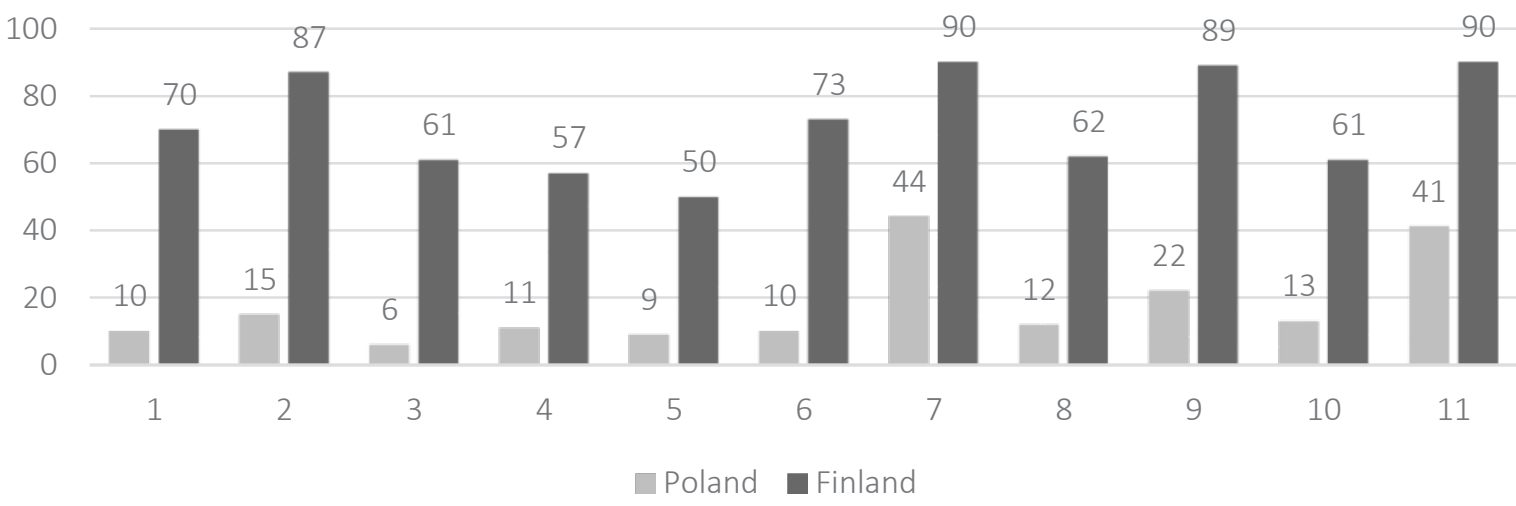

Figure 3. Percentage of enterprises using cloud computing services in 2018 by type of business activity

2 For all business categories, the data refer to the enterprises in the " 10 persons employed or more" class.

3 Sections and divisions according to Polish Classification of Businesses PKD 2007.

4 The following grouping formula is used for the "ICT_T" sector: $26.1+26.2+26.3+26.4+26.8+46.5+58.2+61+62+63.1+95.1$. 
"6. Accommodation" (10\%). The data in the figure shows a large difference between the maximum and minimum values. For Poland, this difference is 7.3-fold, while for Finland only 1.8-fold. Therefore, determining the factors that influence the use of clouds can help reduce the max-min distance.

Based on statistical data regularly published by Statistics Poland and Eurostat, one can conclude that interest in cloud computing is growing annually both in Poland and other EU countries, with growth rates differing among countries, along with the level of cloud use depending on the business size and type.

\subsection{Research to date}

The use of cloud computing in business is closely related to decisions on changing the IT structure, information processes, using new software and information systems in the business process and implementing innovations. Company managers often make such decisions taking into account the information and IT needs of the company, economic profitability of innovative undertakings, possibilities of integration with currently used systems and applications, the manager's vision and his or her trust in innovative solutions, data security, examples of similar applications in the business environment of the company, etc. Technology acceptance models are often used to facilitate decision making at the appropriate level of the management hierarchy. Today, the most useful cloud computing model is UTAUT: Unified Theory of Acceptance and Use of Technology (Venkatesh et al., 2003). The authors have proven that:

- the effect of expected performance on behavioral intentions depends on gender and age, with a stronger influence of men and younger workers;

- the effect of expected effort on behavioral intentions depends on gender, age, and experience. A stronger effect was observed for women, older workers and those with limited experience;

- social impact on behavioral intentions depends on gender, age, voluntarity, and experience, with the effect being stronger for women, older workers, under conditions of mandatory use and with limited experience;

- the impact of conditions facilitating technology use must be assessed based on age and experience, with the effect being stronger for older workers with growing experience.

In summary, according to the UTAUT model, the factors influencing technology acceptance include age, gender, and experience of employees.

Other authors complemented the existing model, thus creating UTAUT2, according to which "Hedonistic motivation", "Value/Price" and "Experience and habits" greatly influence the decision to implement new technology (Shao \& Siponen, 2011).

Previous studies often analyzed factors influencing the use of cloud technologies. For example, Tripathi and Jigeesh (2013) studied the right choice, integrity and confidentiality of technology, software licensing issues, reduction of the total cost of ownership, manoeuvrability and flexibility as major factors in the acceptance of cloud computing services. Other authors focus on twelve factors in the use of cloud technologies, which include the impact of competition, external support, knowledge of cloud use for decision making, employees' knowledge of the cloud, the intensity of information used, costs, service opportunities, security and privacy, etc. (Tehrani \& Shirazi, 2014). In contrast, Hassan (2017) verifies four hypotheses related to the impact of perceived benefits, support for top management, IT resources, and the impact of the external environment on the acceptance of cloud technologies.

Other papers have been also published periodically, including on the adoption of cloud technologies in small and medium-sized enterprises to increase their future competitiveness (Alshamaila, Papagiannidis, \& Li, 2013), the motivation for the use of cloud computing by IT specialists (Sharma, Al-Badi, Govindaluri, \& Al-Kharusi, 2016) or case studies of various cloud service providers, which list nine key and fifteen secondary factors influencing the adoption of cloud technology. These factors range from technological issues to broader organizational and environmental issues (Morgan \& Conboy, 2013). 
Even if there are many publications on the factors determining the use of cloud computing, and the new ones are at the stage of creation, to date, we have not found any research related to the impact of various factors on the use of cloud technologies, taking into account the type of business.

Identification of factors that affect the extent of cloud computing use in enterprises of various business types and the significant diversity of these levels across EU countries can serve as an incentive for the use of cloud technologies and contribute to their popularization in Poland.

The growing interest in the application of cloud technologies in enterprises and the significant variation in their actual use across the EU leads to the formulation of a basic research problem for this study, in particular, related to the following questions:

- Why does the level of cloud computing usage differ significantly across the EU?

- What factors and to what extent affect the level of cloud computing use by companies (taking into account their business type)?

\section{AIMS}

This paper aims to identify the factors and assess their influence on the level of cloud computing use in the management of the EU enterprises, taking into account business activity types.

\section{METHODS}

The following factors have been selected for statistical analysis in this study:

- $\quad$ F2 (Enterprises having a website, \%). A company that advertises through its website will usually use ICT built using cloud services. These include e-mail portals, information storage, and sharing, etc. If the company's website additionally has interactive features, these can be treated as a direct indicator of a company's readiness to use ICT. This indicator ("Having a website or homepage") is also used by Eurostat (European Commission, 2018b, p. 5).
F3 (Enterprises that employ ICT specialists, $\%)$. Cloud technologies are not core technologies, and their effective implementation and use require expertise and experience of ICT specialists. The employment of IT professionals will certainly promote the use of this technology. A similar indicator ("Employ ICT specialist") is used by Eurostat to characterize digitization processes (European Commission, 2018b, p. 5).

- F4 (Enterprise provided training to their personnel to develop/upgrade their ICT skills, $\%)$. The provision of such training promotes a company's use of modern technological solutions. The provision of IT training of any type to ICT professionals and other employees is the subject of statistical reports required by the relevant EU Commission Regulation (EU Commission, 2017, p. 10).

- $\quad$ F5 (Percentage of the ICT sector in GDP, \%). It seems justified to say that the higher the ICT share in GDP, the greater the country's willingness to implement new technologies and the more companies use cloud computing.

- F6 (Percentage of ICT personnel in total employment, \%). Such information may characterize the degree of preparedness to adopt new technologies. Relevant data for EU countries are periodically collected and published by Eurostat (European Commission, 2018d, p. 11).

- $\quad$ F7 (Employed ICT specialists - total, \%). The total employment ratio of ICT specialists undoubtedly characterizes the tendency of various enterprises to implement innovative solutions, including services allowing for effective virtualization of the company's business activity.

- F8 (Employed persons with ICT education by age, \%). The higher the percentage of people with ICT education, the greater willingness to use ICT solutions. In this study, only a group aged 35 to 74 was analyzed. This is because every year, the percentage of people with basic or more than just the basic level of digital skills increases. Mainly young people have 
such skills. For example, in 2017 as many as $85 \%$ of people in Poland declaring possession of advanced digital skills were young, i.e. between 16 and 24 years. $72 \%$ of those between 25 and 34 years also declared having advanced digital skills (Eurostat, 2019i). To the contrary, older people rarely declare having advanced digital skills. Thus, the percentage of people aged between 35 and 74 with ICT education may be one of the measures of the country's readiness to use modern ICT.

- $\quad$ F9 (Individuals who have basic or above basic overall digital skills, \%). The higher the percentage of such people, the greater the use of new technologies, including cloud computing. Data on an individual's level of digital literacy provide important information, which is also recorded annually in EU countries and published by Eurostat (European Commission, 2018d, p. 8).

- F10 (Individuals carried out training paid or provided by the employer to improve skills relating to the use of computers, software, or applications, \%). This indicator is needed to collect statistics on ICT skills and qualifications of individuals (EU Commission, 2017, p. 19).

The factors listed and grouped in this way, which may influence the level of cloud computing use in enterprises, the research problem identified above, together with the research objective, allow the formulation of main and auxiliary research hypotheses:

H1: There is a relationship between the level of cloud computing use in companies with varied types of business and

\section{H1.1: Enterprises having a website (F2);}

H1.2: Enterprises that employ ICT specialists (F3);

H1.3: Percentage of enterprises that provide training in ICT skills to their employees (F4);

H1.4: ICT share in national GDP (F5);

H1.5: Percentage of ICT employees in total employment in the country (F6);
H1.6: Employment of ICT specialists in the country (F7);

H1.7: Percentage of employees with ICT education by age (F8);

H1.8: Percentage of people with basic or advanced digital skills (F9); and

H1.9: The percentage of persons in the country who have received training paid or provided by their employer and intended to improve skills in the use of computers, software, or applications (F10).

This study verified the existence and degree of influence of the nine selected factors (Table 2, F2-F10) on the level of cloud computing use across the EU by type of business (Table 2, F1) using correlation analysis. The analysis of the $r$-Pearson correlation was based on Eurostat statistics. Table 2 presents a detailed list of the developed statistical tables, analyzed factors, and their sources. As a result, 324 tables with statistical data were analyzed. Geographical scope of the analyzed data - all EU countries, time range - years 2014-2018.

Eurostat's statistic tables on enterprises (F1-F4 in Table 2) present data without companies from the financial sector Commission Regulation (EU) 2017/1515 dated August 31, 2017 provides for the collection of the information analyzed only for these enterprise categories (Commission EU, 2017, pp. 11-12).

Gaps in data in the statistical tables have been filled in based on hot deck donor imputation (Piasecki, 2014; Pokerp, 2018). Values from previous years (if indicated) were the donors.

To assess correlation strength, the following $r$-Pearson correlation coefficient scale was adopted (the colors used in the figures are shown in brackets):

- $0 \leq r \leq 0.3$ - no or very weak correlation (no color);

- $0.3<r \leq 0.5$ - moderate correlation ( $\square$ );

- $\quad 0.5<r \leq 0.7-$ strong correlation $(\square)$;

- $\quad 0.7<r \leq 1-$ very strong correlation $(\square)$; 
Table 2. List of tables with statistical data

Source: Developed by the author based on Eurostat (https://ec.europa.eu/eurostat).

\begin{tabular}{|c|c|c|c|}
\hline Factors & Name of Eurostat's statistical table group & Analyzed factor & Time range \\
\hline F1 & Cloud computing services (Eurostat, 2019a) & $\begin{array}{l}\text { Buy cloud computing services used over the } \\
\text { internet }(\%)\end{array}$ & 2014-2018 \\
\hline $\mathrm{F} 2$ & Websites and functionalities (Eurostat, 2019b) & Enterprises having a website (\%) & $2014-2018$ \\
\hline F3 & Enterprises that employ ICT specialists (Eurostat, 2019c) & Enterprises that employ ICT specialists (\%) & $2014-2018$ \\
\hline F4 & $\begin{array}{l}\text { Enterprises that provided training to develop/upgrade } \\
\text { ICT skills of their personnel (Eurostat, 2019d) }\end{array}$ & $\begin{array}{l}\text { Enterprise provided training to their personnel to } \\
\text { develop/upgrade their ICT skills (\%) }\end{array}$ & 2014-2018 \\
\hline F5 & Percentage of the ICT sector in GDP (Eurostat, 2019e) & Percentage of the ICT sector in GDP (\%) & $2014-2016$ \\
\hline F6 & $\begin{array}{l}\text { Percentage of the ICT personnel in total employment } \\
\text { (Eurostat, 2019f) }\end{array}$ & $\begin{array}{l}\text { Percentage of the ICT personnel in total } \\
\text { employment (\%) }\end{array}$ & 2014-2016 \\
\hline $\mathrm{F7}$ & Employed ICT specialists - total (Eurostat, 2019g) & Employed ICT specialists - total (\%) & $2014-2017$ \\
\hline F8 & $\begin{array}{l}\text { Employed persons with ICT education by age (Eurostat, } \\
\text { 2019h) }\end{array}$ & Employed persons with ICT education by age (\%) & 2014-2017 \\
\hline F9 & Individuals' level of digital skills (Eurostat, 2019i) & $\begin{array}{l}\text { Individuals who have basic or above basic overall } \\
\text { digital skills (\%) }\end{array}$ & 2015-2017 \\
\hline F10 & Way of obtaining ICT skills (Eurostat, 2019j) & $\begin{array}{l}\text { Individuals carried out training paid or provided by } \\
\text { the employer to improve skills relating to the use of } \\
\text { computers, software or applications (\%) }\end{array}$ & 2018 \\
\hline
\end{tabular}

A significance level of $p \leq 0.05$ was accepted to assess the statistical significance of the $r$-Pearson correlation coefficient. With this level, the auxiliary research hypotheses H1.1-H1.9 will be verified. The main $\mathrm{H} 1$ research hypothesis may be verified positively if there is a statistically significant correlation for all the factors (positive verification of auxiliary hypotheses), partially positively if some factors exhibit a statistically significant correlation, and negatively in the case of lack of correlation or its statistical insignificance for the analyzed factors.

$\mathrm{IBM}^{\circledR}$ SPSS $^{\circledR}$ Statistics, version 25.0.0.1, was used for correlation analysis.

\section{RESULTS}

The analysis of the correlation of factor F1 (cloud computing use, Table 2) with nine other factors F2-F10 was performed for all eleven business types and with data available for each of the years 2014-2018. Types of business activities are given in Table 1.

Table 3 presents the results of the correlation analysis. Coefficients of correlations, which are statistically insignificant $(p>0.05)$, are written in red, bold italics font. Additionally, the table for factors F2-F9 includes, in the appropriate cells, graphical visualizations of the change in $r$-Pearson correlation coefficient over the years with available statis- tical data. Zero values in some cells result from a lack of data for relevant factors and years.

Based on the results of the analysis of the correlation between factor F1 and individual factors F2-F10 presented in Table 3, one can conclude the following:

- $\quad$ F2 (Enterprises having a website, \%) - the correlation for most business types is strong or very strong, and only for the "Accommodation" type, it is moderate across all the years $(p \leq 0.038)$;

- F3 (Enterprises that employ ICT specialists, \%) - in $60 \%$ of cases the correlation between F1 and F3 is statistically insignificant $(0.055 \leq p \leq 0.953)$, and only for the "Electricity, gas, steam, air conditioning and water supply" businesses, the correlation is strong or moderate $(0.001 \leq p \leq 0.026)$, and for "ICT sector" and "Professional, scientific and technical activities", it was moderate in recent years $(0.002 \leq p \leq 0.046)$;

- F4 (Enterprise provided training to their personnel to develop/upgrade their ICT skills, $\%)$ - for most business types, the correlation is statistically significant $(p \leq 0.033)$, but for $9 \%$ of the cases it was still insignificant $(0.061 \leq p \leq 0.363)$;

- $\quad$ F5 (Percentage of the ICT sector in GDP, \%) - in most cases (about $85 \%$ of all values), the 
Table 3. Correlation analysis results

Source: Developed by the author.

\begin{tabular}{|c|c|c|c|c|c|c|c|c|c|c|c|}
\hline No. & The type of economic activity & Years & $\mathrm{F} 2$ & $\mathrm{~F} 3$ & $\mathrm{~F} 4$ & F5 & F6 & F7 & F8 & F9 & F10 \\
\hline \multirow{5}{*}{1} & \multirow{5}{*}{ Manufacturing } & 2014 & 0.582 & 0.277 & 0.403 & 0.198 & 0.500 & 0.630 & 0.623 & 0.000 & 0.000 \\
\hline & & 2015 & 0.581 & 0.299 & 0.446 & 0.222 & 0.509 & 0.634 & 0.687 & 0.564 & 0.000 \\
\hline & & 2016 & 0.654 & 0.370 & 0.507 & 0.314 & 0.562 & 0.802 & 0.702 & 0.682 & 0.000 \\
\hline & & 2017 & 0.695 & 0.438 & 0.562 & 0.000 & 0.000 & 0.767 & 0.714 & 0.661 & 0.000 \\
\hline & & 2018 & 0.706 & 0.524 & 0.668 & 0.000 & 0.000 & 0.000 & 0.000 & 0.000 & 0.746 \\
\hline \multirow{5}{*}{2} & \multirow{5}{*}{$\begin{array}{l}\text { Electricity, gas, steam, air } \\
\text { conditioning and water supple }\end{array}$} & 2014 & 0.622 & 0.598 & 0.719 & 0.237 & 0.596 & 0.669 & 0.659 & 0.000 & 0.000 \\
\hline & & 2015 & 0.501 & 0.520 & 0.698 & 0.085 & 0.362 & 0.635 & 0.743 & 0.579 & 0.000 \\
\hline & & 2016 & 0.639 & 0.512 & 0.662 & 0.249 & 0.442 & 0.731 & 0.756 & 0.617 & 0.000 \\
\hline & & 2017 & 0.577 & 0.394 & 0.629 & 0.000 & 0.000 & 0.663 & 0.716 & 0.620 & 0.000 \\
\hline & & 2018 & 0.629 & 0.388 & 0.676 & 0.000 & 0.000 & 0.000 & 0.000 & 0.000 & 0.745 \\
\hline \multirow{5}{*}{3} & \multirow{5}{*}{ Construction } & 2014 & 0.442 & 0.033 & 0.221 & 0.181 & 0.485 & 0.539 & 0.598 & 0.000 & 0.000 \\
\hline & & 2015 & 0.471 & -0.018 & 0.328 & 0.196 & 0.450 & 0.549 & 0.613 & 0.510 & 0.000 \\
\hline & & 2016 & 0.632 & 0.023 & 0.404 & 0.351 & 0.581 & 0.738 & 0.647 & 0.670 & 0.000 \\
\hline & & 2017 & 0.505 & 0.173 & 0.500 & 0.000 & 0.000 & 0.698 & 0.695 & 0.665 & 0.000 \\
\hline & & 2018 & 0.664 & 0.291 & 0.502 & 0.000 & 0.000 & 0.000 & 0.000 & 0.000 & 0.692 \\
\hline \multirow{5}{*}{4} & \multirow{5}{*}{$\begin{array}{l}\text { Wholesale and retail trade; repair } \\
\text { of motor vehicles and motorcycles }\end{array}$} & 2014 & 0.613 & 0.293 & 0.458 & 0.107 & 0.420 & 0.577 & 0.547 & 0.000 & 0.000 \\
\hline & & 2015 & 0.600 & 0.097 & 0.483 & 0.149 & 0.421 & 0.574 & 0.592 & 0.510 & 0.000 \\
\hline & & 2016 & 0.778 & 0.296 & 0.621 & 0.272 & 0.496 & 0.806 & 0.683 & 0.724 & 0.000 \\
\hline & & 2017 & 0.714 & 0.382 & 0.644 & 0.000 & 0.000 & 0.739 & 0.646 & 0.661 & 0.000 \\
\hline & & 2018 & 0.767 & 0.486 & 0.573 & 0.000 & 0.000 & 0.000 & 0.000 & 0.000 & 0.666 \\
\hline \multirow{5}{*}{5} & \multirow{5}{*}{ Transportations and storage } & 2014 & 0.417 & 0.273 & 0.417 & 0.144 & 0.401 & 0.472 & 0.550 & 0.000 & 0.000 \\
\hline & & 2015 & 0.485 & 0.336 & 0.487 & 0.236 & 0.469 & 0.480 & 0.516 & 0.470 & 0.000 \\
\hline & & 2016 & 0.723 & 0.398 & 0.653 & 0.423 & 0.615 & 0.722 & 0.558 & 0.663 & 0.000 \\
\hline & & 2017 & 0.670 & 0.387 & 0.536 & 0.000 & 0.000 & 0.696 & 0.622 & 0.673 & 0.000 \\
\hline & & 2018 & 0.782 & 0.366 & 0.715 & 0.000 & 0.000 & 0.000 & 0.000 & 0.000 & 0.657 \\
\hline \multirow{5}{*}{6} & \multirow{5}{*}{ Accommodation } & 2014 & 0.387 & -0.184 & 0.175 & 0.076 & 0.368 & 0.471 & 0.547 & 0.000 & 0.000 \\
\hline & & 2015 & 0.369 & 0.040 & 0.440 & 0.192 & 0.392 & 0.486 & 0.622 & 0.441 & 0.000 \\
\hline & & 2016 & 0.392 & -0.011 & 0.491 & 0.482 & 0.552 & 0.666 & 0.509 & 0.583 & 0.000 \\
\hline & & 2017 & 0.480 & 0.150 & 0.393 & 0.000 & 0.000 & 0.608 & 0.510 & 0.597 & 0.000 \\
\hline & & 2018 & 0.452 & 0.145 & 0.616 & 0.000 & 0.000 & 0.000 & 0.000 & 0.000 & 0.692 \\
\hline \multirow{5}{*}{7} & \multirow{5}{*}{ Information and communication } & 2014 & 0.553 & 0.353 & 0.534 & 0.345 & 0.642 & 0.759 & 0610 & 0.000 & 0.000 \\
\hline & & 2015 & 0.381 & 0.183 & 0.500 & 0.306 & 0.589 & 0.678 & 0.652 & 0.638 & 0.000 \\
\hline & & 2016 & 0.543 & 0.218 & 0.445 & 0.393 & 0.554 & 0825 & 0.672 & 0.673 & 0.000 \\
\hline & & 2017 & 0.390 & 0.479 & 0.491 & 0.000 & 0.000 & 0.739 & 0.602 & 0.649 & 0.000 \\
\hline & & 2018 & 0.580 & 0.549 & 0.501 & 0.000 & 0.000 & 0.000 & 0.000 & 0.000 & 0.630 \\
\hline \multirow{5}{*}{8} & & 2014 & 0.545 & 0.331 & 0.742 & 0.279 & 0.485 & 0.716 & 0.640 & 0.000 & 0.000 \\
\hline & & 2015 & 0.530 & 0.339 & 0.744 & 0.403 & 0.599 & 0.621 & 0.659 & 0.410 & 0.000 \\
\hline & Real estate activities & 2016 & 0.584 & 0.300 & 0.710 & 0.429 & 0.482 & 0.704 & 0.628 & 0.512 & 0.000 \\
\hline & & 2017 & 0.498 & 0.413 & 0.735 & 0.000 & 0.000 & 0.608 & 0.547 & 0.490 & 0.000 \\
\hline & & 2018 & 0.653 & 0.348 & 0.802 & 0.000 & 0.000 & 0.000 & 0.000 & 0.000 & 0.630 \\
\hline & & 2014 & 0.501 & 0.265 & 0.527 & 0.224 & 0.491 & 0.672 & 0.555 & 0.000 & 0.000 \\
\hline & & 2015 & 0.408 & 0.138 & 0.636 & 0.228 & 0.476 & 0.618 & 0.640 & 0.508 & 0.000 \\
\hline 9 & technical activities & 2016 & 0.646 & 0.355 & 0.655 & 0.358 & 0.543 & 0.832 & 0.730 & 0.676 & 0.000 \\
\hline & & 2017 & 0.664 & 0.496 & 0.745 & 0.000 & 0.000 & 0.755 & 0.711 & 0.679 & 0.000 \\
\hline & & 2018 & 0.726 & 0.393 & 0.704 & 0.000 & 0.000 & 0.000 & 0.000 & 0.000 & 0.673 \\
\hline & & 2014 & 0.603 & 0.271 & 0.311 & 0.275 & 0.550 & 0.600 & 0.581 & 0.000 & 0.000 \\
\hline & & 2015 & 0.648 & 0.229 & 0.395 & 0.274 & 0.543 & 0.604 & 0.671 & 0.590 & 0.000 \\
\hline 10 & $\begin{array}{l}\text { Administrative and support } \\
\text { service activities }\end{array}$ & 2016 & 0.661 & 0.171 & 0.330 & 0.408 & 0.638 & 0.766 & 0.597 & 0.664 & 0.000 \\
\hline & & 2017 & 0.623 & 0.223 & 0.367 & 0.000 & 0.000 & 0.680 & 0.643 & 0.621 & 0.000 \\
\hline & & 2018 & 0.664 & 0.266 & 0.507 & 0.000 & 0.000 & 0.000 & 0.000 & 0.000 & 0.718 \\
\hline & & 2014 & 0.534 & 0.476 & 0.435 & 0.274 & 0.550 & 0.686 & 0.585 & 0.000 & 0.000 \\
\hline & & 2015 & 0.403 & 0.397 & 0.407 & 0.254 & 0.502 & 0.600 & 0.621 & 0.583 & 0.000 \\
\hline 11 & ICT sector & 2016 & 0.523 & 0.326 & 0.440 & 0.403 & 0.526 & 0.816 & 0.697 & 0.686 & 0.000 \\
\hline & & 2017 & 0.432 & 0.367 & 0.465 & 0.000 & 0.000 & 0.695 & 0.639 & 0.630 & 0.000 \\
\hline & & 2018 & 0.661 & 0.497 & 0.487 & 0.000 & 0.000 & 0.000 & 0.000 & 0.000 & 0.646 \\
\hline
\end{tabular}


correlation is not statistically significant $(0.051 \leq p \leq 0.732)$ regardless of the type of business activity;

- F6 (Percentage of the ICT personnel in total employment, \%) - the correlation is moderate or strong in most cases, but for almost $12 \%$ of cases it is not statistically significant $(0.052 \leq p \leq 0.084)$;

- $\quad$ F7 (Employed ICT specialists - total, \%) - the correlation is always statistically significant ( $p \leq 0.007)$, usually strong or very strong;

- $\quad$ F8 (Employed persons with ICT education by age, \%) - the correlation is always statistically significant $(p \leq 0.003)$, always strong or very strong;
F9 (Individuals who have basic or above basic overall digital skills, \%) - the correlation is usually strong, always statistically significant $(p \leq 0.034)$;

- F10 (Individuals carried out training paid or provided by the employer to improve skills relating to the use of computers, software or applications, \%) - the correlation is always statistically significant $(p<0.001)$, always strong or very strong.

Based on the conducted correlation analysis, additionally, a ranking of F2-F10 factors was developed for enterprises with various types of business activities (Table 4). This ranking shows the essence of individual factors and their influence on the level of cloud computing use in enterprises.

Table 4. Ranking of factors F2-F10 according to the type of business activity

Source: Developed by the author.

\begin{tabular}{|c|c|c|c|c|c|c|c|c|c|c|c|}
\hline No. & & & The $t$ & pe of ecc & omic ac & vity & & & & & \\
\hline \multirow{3}{*}{1} & \multirow{3}{*}{ Manufacturing } & Factors & F10 & F7 & F8 & $\mathrm{F} 2$ & F9 & F6 & $\mathrm{F} 4$ & F3 & F5 \\
\hline & & $r$ & 0.746 & 0.708 & 0.682 & 0.644 & 0.636 & 0.524 & 0.517 & 0.444 & \\
\hline & & Ranking & 1 & 2 & 3 & 4 & 5 & 6 & 7 & 8 & \\
\hline \multirow{3}{*}{2} & \multirow{3}{*}{$\begin{array}{l}\text { Electricity, gas, steam, air } \\
\text { conditioning and water supple }\end{array}$} & Factors & F10 & F8 & $\mathrm{F} 4$ & $\mathrm{~F} 7$ & F9 & $\mathrm{F} 2$ & F6 & F3 & F5 \\
\hline & & $r$ & 0.745 & 0.718 & 0.677 & 0.675 & 0.605 & 0.594 & 0.519 & 0.482 & \\
\hline & & Ranking & 1 & 2 & 3 & 4 & 5 & 6 & 7 & 8 & \\
\hline \multirow{3}{*}{3} & \multirow{3}{*}{ Construction } & Factors & F10 & F8 & F7 & F9 & $\mathrm{F} 2$ & F6 & $\mathrm{F} 4$ & F3 & F5 \\
\hline & & $r$ & 0.692 & 0.638 & 0.631 & 0.615 & 0.543 & 0.505 & 0.469 & & \\
\hline & & Ranking & 1 & 2 & 3 & 4 & 5 & 6 & 7 & & \\
\hline \multirow{3}{*}{4} & \multirow{3}{*}{$\begin{array}{l}\text { Wholesale and retail trade; repair } \\
\text { of motor vehicles and motorcycles }\end{array}$} & Factors & $\mathrm{F} 2$ & $\mathrm{~F} 7$ & F10 & F9 & F8 & F4 & F6 & F3 & F5 \\
\hline & & $r$ & 0.695 & 0.674 & 0.666 & 0.632 & 0.617 & 0.556 & 0.445 & & \\
\hline & & Ranking & 1 & 2 & 3 & 4 & 5 & 6 & 7 & & \\
\hline \multirow{3}{*}{5} & \multirow{3}{*}{ Transportations and storage } & Factors & F10 & $\mathrm{F} 2$ & F9 & $\mathrm{F} 7$ & $\mathrm{~F} 4$ & $\mathrm{~F} 8$ & F6 & F3 & F5 \\
\hline & & $r$ & 0.657 & 0.615 & 0.602 & 0.592 & 0.562 & 0.561 & 0.542 & 0.384 & \\
\hline & & Ranking & 1 & 2 & 3 & 4 & 5 & 6 & 7 & 8 & \\
\hline \multirow{3}{*}{6} & \multirow{3}{*}{ Accommodation } & Factors & F10 & $\mathrm{F} 7$ & F6 & F8 & F9 & $\mathrm{F} 4$ & F2 & F3 & $\mathrm{F} 5$ \\
\hline & & $r$ & 0.692 & 0.558 & 0.552 & 0.547 & 0.540 & 0.485 & 0.416 & & \\
\hline & & Ranking & 1 & 2 & 3 & 4 & 5 & 6 & 7 & & \\
\hline \multirow{3}{*}{7} & \multirow{3}{*}{ Information and communication } & Factors & F7 & F9 & F8 & $\mathrm{F} 10$ & F6 & $\mathrm{F} 4$ & $\mathrm{~F} 2$ & F3 & F5 \\
\hline & & $r$ & 0.750 & 0.653 & 0.634 & 0.630 & 0.595 & 0.494 & 0.489 & & \\
\hline & & Ranking & 1 & 2 & 3 & 4 & 5 & 6 & 7 & & \\
\hline \multirow{3}{*}{8} & \multirow{3}{*}{ Real estate activities } & Factors & F7 & F9 & F8 & F10 & F6 & F4 & $\mathrm{F} 2$ & F3 & F5 \\
\hline & & $r$ & 0.747 & 0.662 & 0.630 & 0.618 & 0.562 & 0.522 & 0.471 & 0.413 & \\
\hline & & Ranking & 1 & 2 & 3 & 4 & 5 & 6 & 7 & 8 & \\
\hline \multirow{3}{*}{9} & \multirow{3}{*}{$\begin{array}{l}\text { Professional, scientific and } \\
\text { technical activities }\end{array}$} & Factors & F7 & F10 & F8 & $\mathrm{F} 4$ & F9 & $\mathrm{F} 2$ & F6 & F3 & F5 \\
\hline & & $r$ & 0.719 & 0.673 & 0.659 & 0.654 & 0.621 & 0.589 & 0.504 & 0.415 & \\
\hline & & Ranking & 1 & 2 & 3 & 4 & 5 & 6 & 7 & 8 & \\
\hline \multirow{3}{*}{10} & \multirow{3}{*}{$\begin{array}{l}\text { Administrative and support } \\
\text { service activities }\end{array}$} & Factors & F10 & F7 & $\mathrm{F} 2$ & F9 & F8 & F6 & $\mathrm{F} 4$ & F5 & $\mathrm{F3}$ \\
\hline & & $r$ & 0.718 & 0.663 & 0.640 & 0.625 & 0.623 & 0.577 & 0.423 & 0.408 & \\
\hline & & Ranking & 1 & 2 & 3 & 4 & 5 & 6 & 7 & 8 & \\
\hline \multirow{3}{*}{11} & \multirow{3}{*}{ ICT sector } & Factors & $\mathrm{F7}$ & F10 & F8 & F9 & $\mathrm{F6}$ & F2 & $\mathrm{F} 4$ & F3 & F5 \\
\hline & & $r$ & 0.699 & 0.646 & 0.636 & 0.633 & 0.526 & 0.511 & 0.447 & 0.434 & \\
\hline & & Ranking & 1 & 2 & 3 & 4 & 5 & 6 & 7 & 8 & \\
\hline
\end{tabular}


Source: Developed by the author.

\begin{tabular}{|c|c|c|}
\hline Hypothesis & Factor & Verified by \\
\hline $\begin{array}{l}\text { H1. There is a relationship between the level of cloud computing use in companies with varied types } \\
\text { of business and }\end{array}$ & - & Partially positive \\
\hline H1.1. Enterprises having a website & $\mathrm{F} 2$ & Positive \\
\hline H1.2. Enterprises that employ ICT specialists & $\mathrm{F} 3$ & Partially positive \\
\hline H1.3. Percentage of enterprises that provide training in ICT skills to their employees & F4 & Positive \\
\hline H1.4. ICT share in national GDP & F5 & Negative \\
\hline H1.5. Percentage of ICT employees in total employment in the country & F6 & Positive \\
\hline H1.6. Employment of ICT specialists in the country & F7 & Positive \\
\hline H1.7. Percentage of employees with ICT education by age & F8 & Positive \\
\hline H1.8 Percentage of people with basic or advanced digital skills & F9 & Positive \\
\hline $\begin{array}{l}\text { H1.9. The percentage of persons in the country who have received training paid or provided by their } \\
\text { employer and intended to improve skills in the use of computers, software or applications }\end{array}$ & F10 & Positive \\
\hline
\end{tabular}

The values of the correlation coefficient in Table 4 were calculated as an average for 2014-2018.

The research presented in this paper allows for verifying research hypotheses based on the existence of a statistically significant correlation between individual factors F2-F10 and the level of cloud computing use (F1). Table 5 presents the verification results.

\section{DISCUSSION}

The analysis also presents some emerging trends. For example:

- Factors F2, F4, and F7, F8 for some activities exhibit a continuous increase in the correlation coefficient, which means that the impact of selected factors on the level of cloud computing use in enterprises is increasing.

- In recent years, the employment of ICT specialists in companies (F3) has played an increasingly important role in the use of cloud computing. The correlation increases and often changes from statistically insignificant to significant.

- The effect of the F3 factor on cloud computing use is often statistically insignificant, but for businesses in the "Electricity, gas, steam, air conditioning and water supply" category, it is strong or moderate. For businesses in the "ICT sector" and "Professional, scientific and technical activities", the correlation has been moderate in recent years. This could mean that the recruitment of ICT specialists in some sectors significantly contributes to the intensive use of modern information solutions. However, this factor has no impact on the level of use of cloud technologies for businesses in "Construction", "Accommodation", and "Administrative and support service activities".

- Contrary to expectations, the percentage contribution of the ICT sector to the national GDP (factor F5) has almost no impact on the use of cloud technologies.

- The results in Table 3 confirm that the degree of computing cloud use F1 and factors F7, F8, and F9 are correlated to some extent. This correlation is usually strong or very strong. Only for two business types, "Transportation and storage" and "Accommodation", this correlation is moderate.

- The ranking presented in Table 4 shows that, depending on the type of business of an enterprise, F7 and F10 are the most important of the analyzed factors. The correlation is always strong or very strong for them.

- As can be seen in the ranking, factor F3 has the least impact on the level of cloud technologies use, i.e. the percentage of companies recruiting ICT specialists has the least impact on the overall level of cloud computing use.

This correlation analysis shows significant variation in the impact of the nine selected factors on the use of cloud technologies in enterprises in various industries.

The observed trends can be the basis for discussion and become a topic for further detailed research. 


\section{CONCLUSION}

The main conclusions that can be drawn as a result of the study and testing the research hypotheses relate to the level of cloud computing use in companies in different countries, depending on a company's website, the provision of training to employees, the percentage of ICT employees in total employment levels in a given country, the employment of ICT specialists in the country, the percentage of professionally active people with ICT education (by age), the percentage of people with basic or advanced digital skills, the percentage of people providing training paid or provided by the employer. The level of cloud computing use does not depend on the share of the ICT sector in the national GDP and depends partially on companies employing ICT specialists.

Managers can use the results obtained in managing the IT structure of enterprises in various industries. Proven research hypotheses can be used to develop comprehensive activities for a company's IT innovation implementation. The results may be used by management for the development of the company's development strategy and its virtualization.

Further, continuing this research, it is possible to determine the degree of influence of various factors on the use of cloud computing in different functional areas of enterprises. Moreover, it would be useful to compare the results obtained for EU countries with those for other countries around the world. This would allow drawing conclusions about global trends.

\section{ACKNOWLEDGMENT}

This paper emerged as part of the work on a grant for a research project conducted by the research and teaching staff of the Faculty of Economic Sciences at the University of Warmia and Mazury in Olsztyn in 2020. The title of the project is "Information as a factor in managing municipal, water and energy resources".

\section{REFERENCES}

1. Alshamaila, Y., Papagiannidis, S., \& Li, F. (2013). Cloud computing adoption by SMEs in the north east of England: A multi-perspective framework. Journal of Enterprise Information Management, 26(3), 250-275. https://doi. org/10.1108/17410391311325225

2. European Commission. (2018a). Digital Economy and Society Index 2018 Report (14 May 2018). Retrieved from https://ec.europa. eu/digital-single-market/en/news/ digital-economy-and-societyindex-2018-report

3. European Commission. (2018b). Digital Economy and Society Index Report, Integration of Digital Technology. Retrieved from http:// ec.europa.eu/newsroom/dae/ document.cfm?doc_id=52243

4. European Commission. (2018c). Digital Economy and Society Index Report, Connectivity. Broadband market developments in the EU. Retrieved from http://ec.europa. eu/newsroom/dae/document. cfm?doc_id $=52245$

5. European Commission. (2018d). Digital Economy and Society Index Report, Human Capital. Digital Inclusion and Skills. Retrieved from http://ec.europa.eu/newsroom/dae/document.cfm?doc_ $\mathrm{id}=52247$

6. Eurostat. (2019a). Cloud computing services. Retrieved from http://appsso.eurostat.ec.europa. eu/nui/show.do?dataset=isoc_cicce_use\&lang=en

7. Eurostat. (2019b). Websites and functionalities. Retrieved from http://appsso.eurostat.ec.europa. eu/nui/show.do?dataset=isoc ciweb\&lang=en

8. Eurostat. (2019c). Enterprises that employ ICT specialists. Retrieved from http://appsso.eurostat.ec.europa.eu/nui/ show.do?dataset=isoc_ske_ itspen $2 \&$ lang $=$ en

9. Eurostat. (2019d). Enterprises that provided training to develop/ upgrade ICT skills of their personnel. Retrieved from http:// appsso.eurostat.ec.europa.eu/ nui/show.do?dataset=isoc_ske_ ittn2\&lang=en

10. Eurostat. (2019e). Percentage of the ICT sector in GDP. Retrieved from http://appsso.eurostat.ec.europa. eu/nui/show.do?dataset=isoc bde15ag\&lang=en

11. Eurostat. (2019f). Percentage of the ICT personnel in total employment. Retrieved from http://appsso.eurostat.ec.europa. eu/nui/show.do?dataset=isoc bde15ap\&lang=en

12. Eurostat. (2019g). Employed ICT specialists - total. Retrieved from http://appsso.eurostat.ec.europa. eu/nui/show.do?dataset=isoc_sks_ itspt\&lang=en 
13. Eurostat (2019h). Employed persons with ICT education by age. Retrieved from http://appsso.eurostat.ec.europa.eu/ nui/show.do?dataset=isoc_ski_ itage\&lang=en

14. Eurostat. (2019i). Individuals' level of digital skills. Retrieved from http://appsso.eurostat.ec.europa. eu/nui/show.do?dataset=isoc_sk_ dskl_i\&lang=en

15. Eurostat. (2019j). Way of obtaining ICT skills. Retrieved from http:// appsso.eurostat.ec.europa.eu/ nui/show.do?dataset=isoc_sk_ how_i\&lang=en

16. Google Trends. (2020a). Cloud computing, saas, paas, iaas. Retrieved from https:// trends.google.pl/trends/ explore?date $=2006-01-01 \% 20$ 2019-07-27\&q=cloud $\% 20$ computing,saas,paas,iaas

17. Google Trends. (2020b). Cloud computing, saas, paas, iaas. Retrieved from https://bit. ly/2FH8qef

18. Górecki, P. (2014). Czym jest chmura obliczeniowa $i$ "cloudcomputing"? Retrieved from https:// www.tabletowo.pl/2014/08/27/ czym-jest-chmura-obliczeniowa-icloud-computing/

19. Guoding, Y., \& Hong, W. (2003). Cloud computing: a method to realize conceptual computing. Journal of Southeast University (Natural Science Edition), 4. Retrieved from http://en.cnki. com.cn/Article_en/CJFDTOTALDNDX200304029.htm

20. GUS (2020). Miesięczna informacja o podmiotach gospodarki narodowej $w$ rejestrze REGON kwiecień 2020. Retrieved from https://stat.gov.pl/obszarytematyczne/podmioty-gospodarcze-wyniki-finansowe/zmianystrukturalne-grup-podmiotow/ miesieczna-informacja-opodmiotach-gospodarki-narodowej-w-rejestrze-regonkwiecien-2020,4,34.html

21. Hassan, H. (2017). Factors influencing cloud computing adoption in small and medium enterprises. Journal of Information and Communication Technology,
16(1), 21-41. Retrieved from http://e-journal.uum.edu.my/ index.php/jict/article/view/8216

22. Komisja UE. (2017). Rozporzadzenie Komisji (UE) 2017/1515 z dnia 31 sierpnia 2017 r. w sprawie wykonania rozporzadzenia (WE) nr 808/2004 Parlamentu Europejskiego i Rady dotyczacego statystyk Wspólnoty w sprawie społeczeństwa informacyjnego za rok referencyjny 2018. Dziennik Urzędowy Unii Europejskiej, L 226 PL, 01.09.2017.

23. Lohr, S. (2007). Google and I.B.M. Join in 'Cloud Computing' Research. New York Times, October 8, 2007. Retrieved from http://www.csun.edu/pubrels/ clips/Oct07/10-08-07E.pdf

24. Machuga, R. (2017). Wykorzystanie chmur obliczeniowych $\mathrm{w}$ Polsce i w państwach Unii Europejskiej: analiza porównawcza. Informatyka Ekonomiczna, 4(46), 108-120. https://doi.org/10.15611/ ie.2017.4.09

25. Mell, P., \& Grance, T. (2011). The NIST Definition of Cloud Computing. National Institute of Standards and Technology, U.S. Department of Commerce, Special Publication 800-145. Retrieved from https://nvlpubs.nist.gov/ nistpubs/Legacy/SP/nistspecialpublication800-145.pdf

26. Morgan, L., \& Conboy, K. (2013). Key Factors Impacting Cloud Computing Adoption. Computer, 46(10), 97-99. https://doi. org/10.1109/MC.2013.362

27. Piasecki, T. (2014). Metody imputacji w badaniach gospodarstw domowych. Wiadomości Statystyczne, 9(640), 1-20. Retrieved from https://bazekon.uek.krakow. pl/gospodarka/171290845

28. Pokropek, A. (2018). Wybrane statystyczne metody radzenia sobie $\mathrm{z}$ brakami danych. Polskie Forum Psychologiczne, 23(2), 291-310. Retrieved from https://repozytorium. ukw.edu.pl/handle/item/5478

29. Shao, X., \& Siponen, M. (2011). Consumer Acceptance and Use of Information Technology: Adding consumption theory to UTAUT2. Sprouts: Working
Papers on Information Systems, 11(157). Retrieved from https:// www.researchgate.net/publication/277828556_Consumer_Acceptance_and_Use_of_Information_Technology_Adding_consumption_theory_to_UTAUT2

30. Sharma, S. K., Al-Badi, A. H., Govindaluri, S. M., \& AlKharusi, M. H. (2016). Predicting motivators of cloud computing adoption: A developing country perspective. Computers in Human Behavior, 62, 61-69. https://doi. org/10.1016/j.chb.2016.03.073

31. Tehrani, S. R., \& Shirazi, F. (2014). Factors Influencing the Adoption of Cloud Computing by Small and Medium Size Enterprises (SMEs). In S. Yamamoto (Ed.). Human Interface and the Management of Information. Information and Knowledge in Applications and Services. HIMI 2014. Lecture Notes in Computer Science, vol. 8522. Springer, Cham. Retrieved from https://link.springer. com/content/pdf/10.1007\% 2F978-3-319-07863-2_60.pdf

32. Tripathi, S., \& Jigeesh, N. (2013). Review of factors that influence cloud computing adoption. The IUP Journal of Computer Sciences, $\operatorname{VII}(4), 48-59$. Retrieved from https://www.researchgate.net/ publication/323029376_Review_ of_factors_that_influence_cloud_ computing_adoption

33. Venkatesh, V., Morris, M. G., Davis, G. B., \& Davis, F. D. (2003). User Acceptance of Information Technology: Toward a Unified View. MIS Quarterly, 27(3), 425478. Retrieved from https://www. jstor.org/stable/30036540?seq=1 